\title{
Transitional Bilingual Education and Two-Way Immersion Programs: Comparison of Reading Outcomes for English Learners in the United States
}

\author{
By Paul Polanco* \\ Doris Luft de Baker
}

The purpose of this review is to provide a comparison of reading outcomes of the two most popular bilingual programs in the United States: Transitional Bilingual Education and Two-way Bilingual programs. To provide context, we present a theoretical framework and a brief historical perspective on how these programs came to gain popularity. We explored two questions. The first one asks whether there are differences in student outcomes between the programs and whether there are advantages of one program over the other. The second question looks into practical strategies that make these programs beneficial to English learners. For selection methods, we used the previous definition of high-quality articles that included clear outcomes and program definitions. For evaluation of the programs, we used a five-framework model that defines effective bilingual programs that incorporates components of second language literacy development, highquality instruction, and precise definition of the sample population. After the careful review of articles, academic outcomes are presented, indicating that while there might be non-significant differences on reading outcomes, bilingual programs are not detrimental to English learners and there are additional benefits to having a bilingual program beyond potentially enhancing reading outcomes. Also, we found that strategies that work well in a general education classroom for native speakers, also work well for English learners. Finally, we provide recommendations for program development and future research.

Keywords: bilingualism, transitional bilingual education, immersion program, bilingual education, dual-language program.

\section{Introduction}

More than 20 percent of the U.S. population speaks a foreign language at home (U.S. Census Bureau, 2010). The most significant group is the Spanishspeaking population, which makes about 50 percent of the population speaking a foreign language at home (U.S. Census Bureau, 2010). As this population subgroup expands, it is necessary to provide a system that promotes its educational success. By addressing the academic needs of these students, we can support social efficiency and social mobility by ensuring that we have a workforce ready to fully integrate into the economic engine (Labaree, 1997; August \& Shanahan 2006).

*PhD Student, Southern Methodist University, USA.

${ }^{\dagger}$ Assistant Professor, Southern. Methodist University, USA. 
Over several years, there has been a debate on finding the best ways to instruct bilingual students. Through history, we have seen that the perceptions toward bilingualism are strictly related to the political environment in which they develop (Baker, Basaraba, \& Polanco, 2016). In the literature, we find two predominant perceptions toward bilingualism. First, language-as-problem focuses on replacing the first -native- language (L1) of the student and places emphasis on the second language (L2). Researchers of bilingual education often refer to this perception as the subtractive model of bilingualism (Baker, 2011). Second, language-as-resource or additive model, focusing on using the L1 of the student as a resource for developing the L2 (Crawford, 1998). These diverging views have led to the development of various bilingual programs that are worth examining carefully to understand the purpose of each program and its effect on student academic outcomes.

In this paper, we compare and contrast the reading outcomes of English programs and two commonly used bilingual programs, Transitional Bilingual Education (TBE) and Two-Way Immersion (TWI). As the name implies, a transitional bilingual education program focuses on transitioning students from their native language into English using components of the native language and support systems (Slavin \& Cheung, 2005). In contrast, a two-way immersion program combines native and non-native speakers in the same classroom and reading instruction happens in both languages (Kim, Hutchinson, \& Winsler, 2015). To provide context, first, we look at the theoretical framework and provide a historical perspective of how changes in demographics and policies have led to the development and implementation of bilingual programs in the United States. Second, we focus on program descriptions and their respective outcomes on reading measures as indicators of literacy. Finally, we provide a synthesis of the findings in the review and suggest future areas for research and possible limitations of the findings.

\section{Brief History of Bilingual Programs}

Historical evidence points to the existence of bilingual education programs in different parts of the United States dating back to the late 1800s. The most widely implemented program was the German bilingual program, reaching more than 600,000 children by the early $20^{\text {th }}$ century (Ovando, 2003). While the public supported bilingual education during that time, the political environment started shifting toward linguistic and cultural assimilation of immigrants, leading to an ideological competition between English and other languages (Baker, 2011).

Modern bilingual education programs at a national scale date back to the Bilingual Education Act (BEA) introduced in 1967 as an amendment to the Elementary and Secondary Education Act (ESEA) of 1965. BEA is one of the most critical events supporting the rights of minority language speakers. The law did not force school districts to offer bilingual programs. However, it encouraged experimentation and uses of new pedagogical techniques (Crawford, 1989; Nieto, 2009). Under BEA, the government allocated funds for minority language 
speakers to learn in their language as they shifted through English in the classroom (Crawford, 1989; Baker, 2011). The premise of BEA was to provide part of the instruction in the student's native language to ease the transition into mainstream English classrooms. This program is commonly known as a Transitional Bilingual Education (TBE) program (Nieto, 2009). It is important to note that by definition the goal of the transitional bilingual education program was to use the native language (L1) of the students to develop the new language (L2). The goal was not the development of balanced bilingual students who are effectively able to communicate in two languages in academic and social settings, but to ensure that students would be proficient in L2 (Baker, 2011).

After BEA, the Lau v. Nichols court case of 1974 led to the enactment of bilingual education rights for students in San Francisco. Lau v. Nichols was a lawsuit by the parents of Chinese students against the San Francisco public school system. The case questioned whether non-English speakers had the same educational opportunities when instructed in a language different than their native language (Lau v. Nichols, 1974; Baker, 2011; Lyons, 2013). The Supreme Court ruling resulted in the Lau remedies, which prescribed various bilingual programs including English as a Second Language (ESL). However, the Lau remedies were ambiguous, and the bilingual programs and their goals were not clearly defined (Lau v. Nichols, 1974; Lyons, 1990; Ramirez, Yuen, \& Ramey, 1991). While other initiatives came as a consequence of lawsuits, the purpose of bilingual programs continued to be using the native language of students to transition into English literacy as evidenced by the remarks by President Reagan on bilingual education shortly after taking office:

...it is absolutely wrong, and against American concepts to have a bilingual education program that is now openly, admittedly dedicated to preserving their native language and never getting them adequate in English, so they can go out into the market and participate. (Ronald Reagan, 1981, cited in Lyons, 1990)

It was not until 1994 when the Federal government shifted funding for Dual Language programs through a grant program under the reauthorization of the ESEA. In 2001 the amendment called No Child Left Behind (NCLB) had an impact on English learners (ELs) due to its encouragement of English-only instruction (Menken, 2013). The most recent amendment was in 2015 with President Obama's Every Student Succeeds Act. This act promotes high-quality education to bilingual students but no specific guidance on how bilingual instruction would be enacted (Mitchell, 2016). While today various programs are offering bilingual education to maintain the L1, the goal of federal education policy remains the same: use the L1 as a tool to help ELs transition into English so that they can effectively participate in the job market (Menken, 2013; Mitchell, 2016). 


\section{Literature Review}

\section{Theoretical Frameworks}

To understand the educational theories behind bilingual education, it is important to consider the hypotheses developed by Jim Cummins in the 1970's such as the developmental interdependency hypothesis and the threshold hypothesis. This hypothesis suggests that "the development of competence in L2 is partially a function of the type of competence already developed in L1 at the time when intensive exposure to L2 begins" (Cummins, 1979, p.222). The developmental interdependency hypothesis came as a result of the threshold hypothesis in which Cummins (1979) proposed that students must have certain levels of knowledge in L1 to benefit from L2 instruction. While this theory laid the foundation for many modern bilingual education models, the threshold hypothesis was problematic because it was not clear which level of L1 would be necessary for students to be able to benefit from their L1 proficiency (Baker, 2011).

The second component to consider when evaluating the implementation and adoption of bilingual programs is the power associated with the languages taught. The perceived prestige of a language influences how a particular program grows and develops (De Mejía, 2002; Baker, 2011) and how society accepts it and implements it. For example, since the 1960s, Canada implemented a bilingual immersion program. Since that time, bilingual programs have multiplied allowing the development of bilingualism in English and French, national languages that enjoy similar prestige in society (Baker, 2011; Centre for Education Statistics Canada, 2013). In contrast, Spanish in many states in the US is considered of less prestige than English. This difference in the perception of one language to another might lead to differential supports for Spanish compared to English (August \& Shanahan, 2006).

Finally, in this synthesis, the intention is to compare and evaluate two bilingual programs, the Transitional Bilingual Education Program and the Two-way Immersion Program using a multidimensional dynamic framework (August \& Shanahan, 2006). The framework considers five different strands. The first strand consists of understanding the nature of the relationships between the components of language (i.e. phonological processes, second language proficiency, cognitive abilities, educational background) and individual differences. Second, literacy development is a dynamic process that changes as a result of learner's age, previous experience and instruction, and motivation, among other factors. Third, language-minority students "are subject to an additional set of intervening sociocultural influences" related to the language proficiency in their L1 possibly influencing their development of L2. Factors such as immigration, home environment, and differences in discourse and interaction characteristics between children's home and classrooms have consequences on the nature of the first language and how efficiently the students acquire the second one. Fourth, the sociocultural context in which the students are learning the second language influences such acquisition and 
literacy development. For many language-minority students, there are a set of contextual issues affecting learning and language acquisition such as poverty, low social status, and incompatibility between home and school environments, to mention a few. Also, as discussed above, the perceived prestige of the language influences the view, and the motivation students may have toward acquiring the second language (De Mejía, 2002; Baker, 2011). Finally fifth, August and Shanahan (2006) proposed that developing literacy in a second language depends on the amount and quality of instruction provided to these students. Instructional methods, progress monitoring, and teacher preparation among other factors define the quality of schooling. These factors have a direct influence on how students acquire a second language. This multidimensional framework will be used to determine the quality of the bilingual programs used in the studies for this review.

\section{Program Descriptions}

Transitional Bilingual Education (TBE). The history of TBE programs in their purest form can be traced back as an outcome of the Bilingual Education Act of 1967 (Crawford, 1989). Later, as a consequence of Lau vs. Nichols came the Lau Remedies requiring schools to provide instruction in a language that nonnative speakers understand. Programs such as English as a second language (ESL) and TBE programs were the tools that promoted the English language education in non-native speakers (Crawford, 1989; Baker, 2011).

Slavin and Cheung (2005) proposed that TBE programs teach children to read in their L1 through the primary grades while gradually transitioning into English reading instruction between second and fourth grades. There are two forms of TBE: (1) "early-exit" models where students transition to English after a maximum of two years of instruction in L1, usually between second and third grade (Slavin \& Cheung, 2005; Baker, 2011; Kim, Hutchinson, \& Winsler, 2015) and (2) "late-exit" models where students receive L1 reading instruction throughout the elementary grades ensuring reading mastery before continuing with instruction (Slavin \& Cheung, 2005; Baker, 2011; Kim, Hutchinson, \& Winsler, 2015). Other variations of TBE are "paired bilingual" or "alternative immersion" programs (Willig, 1985 cited in Slavin \& Cheung, 2005), but ultimately the goal is the same, to transition students from instruction in their native language to English-only education.

The premise of TBE programs is that, while there might be a lag in performance immediately after transitioning from the bilingual program to English-only, there is a recovery that follows the transition. Moreover, TBE programs address the fundamental promise of education as a tool providing access to economic opportunities and social mobility in the American society, attained through the development of English language competency in children (Mitchell, Destino, Karam, \& Colón-Muñiz, 1999). This idea of transitioning from the native language instruction into English is still prevalent today.

Two-Way Immersion (TWI). This program is also known as "dual language education," "bilingual immersion" or "Spanish immersion" depending on the 
partner language used (Lindholm-Leary \& Block, 2010). These terms are used interchangeably in the literature (Kim, Hutchinson, \& Winsler, 2015). This program originated in Dade County schools in Florida in 1963, where the recently arrived Cuban immigrants established a bilingual program supporting both languages. This program was a success due to the support of Cuban immigrants who were considered educated and well regarded by society in the United States (Crawford, 2004; Baker, 2011). The theoretical framework for TWI programs is rooted in the exchange that occurs between languages which benefit the language development of the students (López \& Tashakkori, 2004a).

TWI combines native and non-native speakers of English in the same classroom where students learn in both languages (Kim, Hutchinson, \& Winsler, 2015). This model of education is one of the most important distinctions of a TWI program when compared to other models of immersion programs as it promotes an environment of equity that values the language and culture of all students in the classroom (Lindholm-Leary \& Block, 2010; Parrish et al., 2006). Another critical distinction in this model is that English never replaces the minority language. Instead, students are expected to function equally in academic and social conversations using both languages. Additionally, the goal of this model is to develop bilingualism and biculturalism in the populations it serves (Baker, 2011; Anderberg \& Ruby, 2013). The Center for Applied Linguistics defines TWI "as a distinctive form of dual language education in which balanced numbers of native English speakers and native speakers of the partner language are integrated for instruction so that both groups of students serve in the role of language model and language learner at different times of the day" (Center for Applied Linguistics, 2015).

Lindholm-Leary (2012) identified two major variants of TWI, often referred to as the 90:10 and 50:50 models. In the 90:10 model, 90\% of the instructional day in kindergarten and first grade is devoted to content instruction in the partner language, which is the language other than English in the program. The remaining $10 \%$, is in English. English time is used to develop oral language proficiency. The teaching of reading is in the target language (i.e., Spanish) for native speakers of the partner language and native English speakers in the classroom. As students move on to second through third grades, $80 \%$ of their instruction is in the target language and the rest in English. While content instruction in English happens in third grade, students are exposed to English print and literature as early as first grade. By the time students reach fourth grade, there is a balance between the target language and English. In the 50:50 model, both groups of students, receive instruction half the time in the target language and the other half in English, throughout their elementary school years. The literature indicates that TWI programs often use highly structured instructional methods and paraprofessionals serve as aides to accomplish the goals of the program (Parrish et al. 2006). 


\section{Methods}

\section{Research Questions and Selection Criteria}

The purpose of this literature synthesis is to provide answers to the following questions:

1. What are the differences in outcomes between the TBE and TWI programs as compared to English-only programs and to each other? If there are differences, is there an advantage on reading outcomes originating from one program over the other?

2. What characteristics of a program yield to more positive reading outcomes for English learners?

To find information related to the two bilingual programs of interest, we searched for peer-reviewed articles that included the terms bilingual program, bilingual education, two-way bilingual, dual language, and transitional bilingual in three ways. First, we searched various databases such as ERIC and Google Scholar for peer-reviewed publications. Second, we looked into the National Literacy Panel Report of Language-Minority Children and Youth, (August \& Shanahan, 2006) which included several peer-reviewed articles and reviews in the field. Finally, we looked at the reference lists to determine whether there were articles relevant to bilingual programs in the U.S. that could help refine the understanding of the outcomes.

Following the methods of other authors in the field (Baker, Basaraba, \& Polanco, 2016), our inclusion criteria covered: (a) empirical studies; (b) focused on pre-K to 12 grades; (c) within the U.S. Initially, 36 articles met the selection criteria selected. To further refine the search, we looked for studies that included (a) a description of participants that included socio-economic status, parental education, and selection criteria; (b) details of the programs being used as interventions for participants; (c) a clear description of outcome measures; and (d) well-defined outcomes of the studies.

Ultimately, we narrowed down the search to high-quality articles that reflected clear descriptions of the two-way immersion and transitional bilingual programs, and that provided clear outcomes linked to the instructional models. To summarize the studies reviewed, an Appendix includes a brief description of the articles, measures, and quality indicators for the selected articles.

\section{Findings}

\section{Programs Benefits and Comparison}

For this literature synthesis, 13 empirical studies searched over summer and fall of 2015, met the selection criteria specified in the methods section. In these articles, authors explored the benefits of various bilingual instructional programs 
by offering commonly used measures to demonstrate the outcomes tied to the programs in question. Below is a synthesis of the selected articles. For ease of understanding of the answers to the research questions, we divided the findings by (1) general outcomes of bilingual programs, (2) TBE compared to English-only, (3) TBE compared to SEI, (4) TWI compared to English-only, (5) TWI compared to TBE. Following previous definitions in the literature, for this review, Englishonly refers to programs where students are taught primarily in English with English-speaking peers without any support on the native language (Valentino \& Reardon, 2015).

Bilingual Programs General Outcomes. Two studies described the general outcomes of bilingual programs. Anderberg \& Ruby (2013) addressed whether three bilingual programs (English with Spanish support, TBE, and Dual Language) have effects on receptive language development on native Spanish speaking preschool students using a pre-post test design. The authors of this review found that there were significant learning effects in English across all programs on measures of receptive vocabulary after two years. Limitations include the starting points of the children placed in the English program classrooms were two standard deviations below the mean in both L1 and L2, and while the students showed progress, this progress might not have been enough to close the reading achievement gap between bilingual students and native English speakers. Another limitation is that this is a correlational study, so there might be other variables beyond program causing the effects on the participants.

A second study by Valentino \& Reardon (2015), followed 13,750 bilingual students who entered school in kindergarten between the 2001-2002 and the 20092010 academic years. The goal of the study was to determine the overall benefits of programs designed to serve non-native speakers by comparing them across programs. Authors found that students in either TBE or TWI showed significant growth from pretest to posttest in English Language Arts and Math when compared to students in English only programs. When comparing students in TBE with students in TWI, findings indicated that students in TWI programs who entered the program with lower scores, showed a faster rate of increase after second grade compared to students who entered the TBE program. Limitations of this correlational study include generalizability as the data for this study came from a single school district which is uniquely diverse ethnically and linguistically. Moreover, authors of this study define effectiveness as outcomes in English and do not consider other factors in the development on bilingual students. Finally, authors did not control for classroom quality indicators.

TBE vs. English-Only. Two studies compared the outcomes of bilingual students in a TBE and English-only programs. A quasi-experimental study by Proctor, August, Carlo, \& Barr (2010) examined the growth of Spanish reading comprehension in bilingual students in second through fifth grade. The authors found no significant differences between students in the TBE and English only programs on the acquisition of reading abilities in English, indicating that bilingual instruction under the TBE program did not represent a disadvantage to children in English reading by comparing students in a TBE program to those in English-only.

In another study, Reese, Gallimore, \& Guthrie (2005) conducted a 
longitudinal study to evaluate ways in which a transition from Spanish to English instruction impacts the achievement of bilingual students between grades 2 and 4 . Results indicated that there was a development of the L1 of the students immediately after transitioning, but they seem to disappear when using academic measures of reading. The authors concluded that issues with program implementation, the learning environment, and lack of development in either language made it difficult for students to transition successfully into English-only had an effect on the outcomes.

TBE and Structured English Immersion (SEI). There are other forms of bilingual programs that have the goal of transitioning students into full English immersion programs, but the methodology includes structured ESL instruction (i.e., Structured English Immersion; Slavin, Madden, Calderón, Chamberlain, \& Hennessy, 2011). Three studies compared the effects of TBE and SEI programs. Slavin et al. (2011), conducted an experimental study comparing outcomes between students attending TBE vs. SEI programs. Findings indicated no significant overall differences on measures of reading in English and Spanish. These results indicate that while students were able to preserve their main language, whether they transitioned into full English (as it is the case in TBE) or whether they received instruction mostly in English, the program made no difference in reading outcomes. Additionally, reading skills developed in the native language faded away after fourth grade.

Similar experimental longitudinal studies (Tong, Irby, Lara-Alecio, \& Mathes, 2008a; Tong, Lara-Alecio, Irby, Mathes, \& Kwok, 2008b) found no differences between a TBE program that uses the native language of students for some established period of time when compared to an SEI model that only uses English as a method of instruction. The authors found that there were no differences between using the native language compared to using English only and that there were no differences in student outcomes between the two programs. This finding demonstrates that using a second language is not detrimental to students learning to read in that language. Furthermore, when the model used was an enhanced form of TBE, where teachers spend more time teaching L1 through explicit instruction, results pointed toward accelerated learning on various measures of reading.

TWI and English-Only. Three studies compared the effects of TWI and English-only programs. In a randomized control trial, Barnett, Yarosz, Thomas, Jung, \& Blanco (2007) compared 79 preschool Spanish-speaking ELs in a TWI with 52 preschool Spanish-speaking ELs in an English-only program within the same district. The authors did not find significant differences between both groups on measures of growth in language and emergent literacy. However, researchers found substantial language development in Spanish vocabulary for students in TWI over students in English immersion programs. In another study that included 659 low-income Hispanic elementary students, Lindholm-Leary and Block (2010) found that students in a TWI performed at similar or higher rates on measures of English when compared to students who were in an English-only program.

There are different types of TWI, so it becomes relevant to analyze whether these differences affect outcomes. Two quasi-experimental studies in kindergarten 
and first grade by Lopez \& Tashakkori (2004a, 2004b) found no significant differences on measures of reading between EL students attending TWI programs that taught $90 \%$ of the time in English and $10 \%$ in Spanish vs. Students attending a TWI program that taught $70 \%$ in Spanish and 30\% in English. Results of this investigation indicate that students who started at different levels of proficiency in measures of reading (i.e., phonics, sight words, narrative and expository writing) were at the same level as students in the alternative program where they learned in English $90 \%$ of the time and $10 \%$ of the time in Spanish.

TWI and TBE. Two studies compared TWI and TBE. Lopez \& Tashakori (2006) compared outcomes for 553 fifth-grade students who participated in either a TWO program or a TBE program. The researchers found that ELs in a TWI required less time to learn English as compared to ELs in a TBE on measures of reading using a statewide standardized assessment. Part of this study was a qualitative study on the perceptions of students on being bilingual. Findings suggest that students in the TWI program appeared to have a positive attitude towards bilingualism that included their pride of knowing that they would preserve their culture, and that being bilingual would be an "asset for their future." Results, however, also indicated no significant differences between students who participated in the TWI program vs. the TBE program in reading mathematics, and science. Another important finding suggested that students who had the highest levels of English proficiency as they entered kindergarten or first grade, also had better academic outcomes.

TWI programs by definition include ELs and English native speakers (Center for Applied Linguistics), so the question remains on who benefits from such programs. In a recent study, Marian, Shook, \& Schroeder (2013) looked at 2009 students in third through fifth grades and explored whether native English speakers benefited from being part of TWI. Native English speakers and EL students in TWI showed significant improvements across grade levels with higher scores on measures of reading and math in later grades in English when compared to students in other programs. The authors concluded that the TWI program is beneficial for ELs and native English speakers in the elementary school by showing an increase in scores as they moved into higher grades as opposed to students in the TBE where scores did not increase across grades on measures of math and reading.

Techniques and Instructional Delivery. Four studies discussed the possible effects of instructional techniques and delivery. Barnett et al., (2007) controlled for high standards of teacher qualifications, ratio, and class size. In other studies, there was the use of paraprofessionals in the classroom assisting the teacher (Barnett et al., 2007; Anderberg \& Ruby, 2013). One quasi-experimental study by Calhoon, Al Otaiba, Cihak, King, \& Avalos, (2007) on first grade TWI students found that using peer-assisted learning strategies, including dyads of students in different reading performances, indicated significantly greater growth on various levels of reading fluency for ELs and native speakers in the TWI program when compared to students in a traditional reading program (Calhoon, Al Otaiba, Cihak, King, \& Avalos, 2007). Cena, Baker, Kame'enui, Baker, Park, \& Smolkowski (2013) found large effects on researcher developed vocabulary measures for ELs 
receiving explicit vocabulary instruction using a scripted program compared to students receiving vocabulary instruction by teachers using a general vocabulary template.

\section{Discussion of Findings}

In this paper, we reviewed the reading outcomes of 13 empirical studies that compared two types of bilingual programs between each other, or to English-only programs. These studies were selected using various quality indicators such as clear description of participants, clear program description, and a precise description of outcome measures. Three major findings came as a result of this review. First, students in any form of bilingual program performed equally to their English-only counterparts. Second, when comparing students in TBE and TWI, students in TWI showed faster growth in measures of reading. Third, in a TWI program native English speakers and non-native speakers benefited from the program and had the added benefit of second language development. Next, we examine these findings using the multidimensional dynamic framework suggested by August and Shanahan, 2006.

For ease of understanding, we used the previously explained five-framework model established by August \& Shanahan (2006) to analyze second-language literacy development for bilingual students. The first dimension refers to the differential effects of the programs based on student individual characteristics. For example, in the study by Anderberg and Ruby (2013) described in Appendix, Table 1, students who started with higher levels of academic and language literacy had higher academic gains compared to students who started kindergarten with lower academic and language literacy. Valentino and Reardon (2015) suggested that differences among students should be accounted for when examining the benefits of bilingual programs compared to English only programs. Unfortunately, studies don't always take these individual differences into account.

The second dimension refers to the importance of considering previous experiences, age, and motivation on the effects of bilingual programs on literacy outcomes. The studies we reviewed here included different populations of students. Thus the effects of bilingual programs are difficult to compare because they were conducted across the grades. For example, the study by Reese, Gallimore, and Guthrie (2005) indicated that by $7^{\text {th }}$ grade, there appeared to be a negative relation between students attending TBE and their academic outcomes $(r$ $=-.48, \mathrm{p}<.01$ ), Thus, when comparing bilingual programs, it is important to compare students in the same grade and across the grades given that language proficiency takes several years to develop (Cummins, 1979).

The third dimension refers to the influence of the native language on the development of literacy in a second language. Considering that the native language of most bilingual students served in the United States is Spanish, it is important to understand how previous exposure to formal Spanish affects both Spanish and English outcomes. In other words, when ELs enter school, they have different levels of native language proficiency that should be taken into account 
when examining their native language and English academic outcomes. All the programs presented in this synthesis used the native language of the student to enhance instruction. However, understanding these differences would help practitioners implement programs that are relevant to students and that enhance the knowledge they already possess while developing a second language.

The fourth dimension refers to the influence of sociocultural factors such as the student background and then honor that background. In a study by LindholmLeary \& Block (2010) involving 659 participants, Hispanic students in TWI compared to their peers in the English-only program. Those in the TWI program performed better than the reference group. The possibility exists that by honoring the previous diverse knowledge and cultural idiosyncrasies students already bring to the classroom could benefit the students in their literacy development when participating in bilingual programs. This will then instill a pride in their cultural background which can be translated into higher motivation and engagement in learning their native language.

The fifth dimension refers to quality of instruction. While the selected studies provided information about classroom dynamic, including time and in some cases resources available such as the amount of language support received by students and the time of transition for students, these indicators are often hard to measure and are dependent upon instructors. A clear understanding of this concept is essential to replicate effective strategies for ELs and continue to close the literacy gap between ELs and native English-speakers. Keeping this framework in mind, below are the answers to the questions that motivated this paper.

\section{What are the Differences in Outcomes between the TWI and TBE Programs as compared to English-only and to each other? Is there an Advantage on reading Outcomes Stemming from one Program over the other?}

When it comes to benefits of TWI and TBE on measures of reading outcomes as compared to English-only programs, the results are more difficult to interpret. Results from 7 of the studies indicated that there were no significant differences on measures of reading when comparing English-only programs to any of the bilingual programs analyzed. This finding is relevant to the field because it confirms previous research that indicates that bilingual programs are not detrimental to ELs and that the acquisition of L1 does not obstruct the development of L2.

Of equal importance is the fact that students in a TBE program, as the name implies, transition into a full English program and Reese, Gallimore, \& Guthrie (2005) found that L1 knowledge developed in students in their elementary years fades away in favor of English skills needed to succeed in the English-only classroom. This effect puts TWI programs in a superior position for language preservation and cultural exchange as the TWI aims to develop balanced bilingual students who can perform equally in both languages. One of the goals of TWI is to have an additive effect on language skills (Baker, 2011) by adding a second language while maintaining and developing the first language. By doing so, 
programs may impact cultural preservation and even cultural pride (Baker, 2011). Native language preservation, development, and maintenance are benefits that may not be evident in the reading outcomes. Nonetheless, they are important aspects of learning two languages (Cummins, 1978; Baker, 2011). Additionally, the measures used are often in the second language. This result combined with the benefit of native language conservation for ELs, benefits for non-ELs, and all students competing in a global market where multilingualism is valuable, demonstrates that there is no academic reason not to provide bilingual services to ELs. A final finding is that when implementing these programs, the difference between the skill levels of students must be a consideration along with instructional support to all students who participate in the program whether they are English native or ELs.

\section{What Characteristics of a Program yielded more Positive reading Outcomes for English Learners?}

When looking for the answer to the second question regarding characteristics of effective programs, all instructional models had evidence of strong curriculum consistently implemented and evidence of the high quality of instruction including a structured classroom environment and program fidelity. Also, there was the presence of a paraprofessional that served as an instructional resource for students. These findings are consistent with Goldenberg's (2013) recommendations for effective practices that include clear instructions, effective modeling of skills, adequate feedback, application of learning, and continued assessments and classroom routines. The use of these practices according to Goldenberg (2013) are a source for positive results on bilingual students.

\section{Limitations}

When making claims about benefits of different bilingual programs it is essential to look at the definitions, specific program goals, and levels of implementation and fidelity to determine the source of the benefits (Baker et al., 2016). Across all the articles reviewed, it is difficult to identify a consistent operational definition of the programs implemented. More specifically, such descriptions do not include specific time dedicated to teaching each language, professional training, the fidelity of implementation, and curriculum used. In the studies, we found variability in these definitions, which makes it difficult to derive conclusions directly linked to the bilingual program. Even after reviewing these studies, questions about the internal validity of the programs remain regarding the quality of instruction the students are receiving and which students are truly benefiting from these programs. It is difficult to identify whether the positive results are coming from high-quality education, from resources used, or from levels of student literacy when entering the program. Additionally, more research is needed on whether these positive outcomes go beyond elementary schools and academic outcomes. For example, it is also important to examine the effects of bilingual programs on the preservation of the students' cultural heritage, and on 
the workforce after they graduate from high school or college (Polanco \& Richards, 2016).

Finally, from these studies, it is not clear how students of different cultural backgrounds fare in these bilingual programs. While these studies focused on benefits for Hispanic students, it is essential to consider that benefits could be different when disaggregating Hispanic groups by place of origin. According to a qualitative study by Lukes (2015), we know that students from different nationalities within the Spanish-speaking world have different general characteristics and trajectories that could affect performance in the classroom. Moreover, we must understand whether the benefits of bilingual programs also transfer to ELs of languages different than Spanish. This transfer is an important factor to take into account, particularly when making policy decisions intended to foster bilingual programs in languages different from Spanish.

\section{Suggested Directions for Future Research}

Based on the previous results we make the following recommendations for future research for determining academic outcomes of bilingual programs:

Explicit description of programs. Programs evaluated should be described in detail in the study. The description should include the goal of the program (i.e., promote bilingualism or using native language as a tool to acquire the L2) time spent teaching each language, professional training, and measures of fidelity of implementation. A clear description will ensure that the outcomes from the programs can be replicated in other places.

Define the meaning of effective instruction for bilingual students. While some of the research in bilingualism provides effective practices for many bilingual students (Goldenberg, 2013), it is still not clear whether these are just good teaching practices that work with every student or whether they are specific to bilingual students. Further exploration of this subject through the implementation of consistent programs, and the monitoring of teaching, will enable practitioners to make better decisions based on results.

Explore the cross-curricular transfer of academic skills. There are very few high-quality studies on the effects of bilingual programs on academic outcomes beyond reading. It is not clear whether these skills are transferred to other subjects such as math, science or social studies. Future studies should look at the possible effects of learning other subjects in the native language.

Promote programs that create balanced bilinguals. There is new evidence that programs that promote bilingualism yield benefits beyond the academic setting including economic benefits. However, these benefits are only evident when the students can communicate academically and socially in both languages fluently (Callahan \& Gándara, 2015). Promoting programs that enable students to attain a practical level of bilingualism will not only have an impact on the students but also on one of the purposes of education: to create a democratic population that is able to make its own decisions and a society that encourages social mobility and social efficiency (Labaree, 1997; August \& Shanahan, 2006). 


\section{Conclusion}

When analyzing the effects of programs offered to bilingual students on reading outcomes, the findings from the literature point to no significant differences in the development of English literacy skills. This finding is important because it demonstrates that students can learn the L2 through the use of their native language. Nevertheless, there are some other benefits worth exploring in the future. For example, studies showed that students in bilingual programs have a faster academic growth rate on measures of literacy and math than students in an English-only program. Moreover, in some cases, bilingual programs were a source of accelerated growth on reading outcomes for students who started at lower levels of reading proficiency than their peers in English-only programs. Finally, TWI programs demonstrated faster growth on literacy outcomes than students who attended TBE programs. This growth rate is worth exploring further to understand what techniques are more practical when teaching bilingual students. An additional benefit of TWI programs could be the simultaneous development of two languages and its influence on cultural preservation and cross-cultural transfer. Future studies should look at measures of L1 compared to L2 and how crosslinguistic transfer occurs in non-native English speakers. On the qualitative side, one study found that the perception of Hispanic students toward bilingualism is that it holds value in society. Future studies should explore in depth how bilingualism is perceived, who has those perceptions, and for whom is bilingual education particularly valuable.

\section{References}

Anderberg, A., \& Ruby, M. F. M. (2013). Preschool Bilingual Learners' Receptive Vocabulary Development in School Readiness Programs. NABE Journal of Research and Practice, 4(1).

August, D., \& Shanahan, T. (2006). Developing literacy in second-language learners: Report of the National Literacy Panel on Language-Minority Children and Youth.

Baker, C. (2011). Foundations of bilingual education and bilingualism (Vol. 79). Multilingual matters.

Baker, D. L., Basaraba, D. L., \& Polanco, P. (2016). Connecting the Present to the Past: Furthering the Research on Bilingual Education and Bilingualism. Review of Research in Education, 40(1), 821-883.

Barnett, W. S., Yarosz, D. J., Thomas, J., Jung, K., \& Blanco, D. (2007). Two-way and monolingual English immersion in preschool education: An experimental comparison. Early Childhood Research Quarterly, 22(3), 277-293.

Callahan, R. M., \& Gándara, P. C. (2015.). The Bilingual Advantage. Bilingual Education and Bilingualism.

Calhoon, M. B., Al Otaiba, S., Cihak, D., King, A., \& Avalos, A. (2007). Effects of a peermediated program on reading skill acquisition for two-way bilingual first-grade classrooms. Learning Disability Quarterly, 30(3), 169-184.

Cena, J., Baker, D. L., Kame'enui, E. J., Baker, S. K., Park, Y., \& Smolkowski, K. (2013). The impact of a systematic and explicit vocabulary intervention in Spanish with Spanish-speaking English learners in first grade. Reading and Writing, 26(8), 12891316. 
Center for Applied Linguistics (2015). Dual Language and Two Way Immersion Programs. Retrieved on October, 2015 from www.cal.org/twi.

Centre for Education Statistics (2013). Youth Bilingualism in Canada. Retrieved on October, 2015 from http://www.statcan.gc.ca/pub/81-004-x/2008004/article/107 67eng.htm

Crawford, J. (1989). Bilingual education: History, politics, theory, and practice. Bilingual Education Serv.

Crawford, J. (1998). Language politics in the USA: The paradox of bilingual education. Social Justice, 50-69.

Crawford, J. (2004). Educating English learners: Language diversity in the classroom. Bilingual Education Serv.

Cummins, J. (1979). Linguistic interdependence and the educational development of bilingual children. Review of educational research, 49(2), 222-251.

De Mejía, A. M. (2002). Power, prestige, and bilingualism: International perspectives on elite bilingual education (Vol. 35). Multilingual Matters.

Goldenberg, C. (2013). Unlocking the Research on English Learners: What We Know-and Don't Yet Know--about Effective Instruction. American Educator, 37(2), 4.

Kim, Y. K., Hutchison, L. A., \& Winsler, A. (2015). Bilingual education in the United States: an historical overview and examination of two-way immersion. Educational Review, 67(2), 236-252.

Labaree, D. F. (1997). Public goods, private goods: The American struggle over educational goals. American Educational Research Journal, 34(1), 39-81.

Lau v. Nichols, 414 U.S. 563, 94 S. Ct. 786, 39 L. Ed. 2d 1 (1974).

Lindholm-Leary, K., \& Block, N. (2010). Achievement in predominantly low SES/ Hispanic dual language schools. International Journal of Bilingual Education and Bilingualism, 13(1), 43-60.

Lindholm-Leary, K. (2012). Success and challenges in dual language education. Theory into Practice, 51(4), 256-262.

López, M. G., \& Tashakkori, A. (2004a). Effects of a two-way bilingual program on the literacy development of students in kindergarten and first grade. Bilingual Research Journal, 28(1), 19-34.

López, M. G., \& Tashakkori, A. (2004b). Narrowing the gap: Effects of a two-way bilingual education program on the literacy development of at-risk primary students. Journal of Education for Students Placed at Risk, 9(4), 325-336.

López, M. G., \& Tashakkori, A. (2006). Differential outcomes of two bilingual education programs on English language learners. Bilingual Research Journal, 30(1), 123-145.

Lukes, M. (2015). Latino Immigrant Youth and Interrupted Schooling: Dropouts, Dreamers and Alternative Pathways to College (Vol. 100). Multilingual Matters.

Lyons, J. J. (1990). The past and future directions of federal bilingual-education policy. The Annals of the American Academy of Political and Social Science, 508(1), 66-80.

Lyons, J. (2013). Opportunity lost: The promise of equal and effective education for emerging bilingual students in the Obama administration. Boulder, CO: Bueno National Policy Center, University of Colorado, Boulder.

Marian, V., Shook, A., \& Schroeder, S. R. (2013). Bilingual two-way immersion programs benefit academic achievement. Bilingual research journal, 36(2), 167-186.

Menken, K. (2013). Restrictive language education policies and emergent bilingual youth: A perfect storm with imperfect outcomes. Theory into Practice, 52(3), 160-168.

Mitchell, C. A. (2016). ELL Advocates Hopeful and Wary of New Federal K-12 Law. Education Week, Online. Retrieved on July, 2016 from http://www.edweek.org/ ew/articles/2016/01/06/ell-advocates-hopeful-and-wary-of-new.html

Mitchell, D. E., Destino, T., Karam, R. T., \& Colón-Muñiz, A. (1999). The politics of 
bilingual education. Educational Policy, 13(1), 86-103.

Nieto, D. (2009). A brief history of bilingual education in the United States. Urban Ed Journal, 61, 61-65.

Ovando, C. J. (2003). Bilingual education in the United States: Historical development and current issues. Bilingual Research Journal, 27(1), 1-24.

Parrish, T. B., Merickel, A., Pérez, M., Linquanti, R., Socias, M., Spain, A., ... \& Delancey, D. (2006). Effects of the Implementation of Proposition 227 on the Education of English Learners, K-12: Findings from a Five-Year Evaluation. Final Report for AB 56 and AB 1116. American Institutes For Research.

Polanco, P., \& Richards, M. (2016). Economic Outcomes of Bilingualism in the United States. [PowerPoint Slides]. Association of Education Finance Policy.

Proctor, C. P., August, D., Carlo, M., \& Barr, C. (2010). Language maintenance versus language of instruction: Spanish reading development among Latino and Latina bilingual learners. Journal of Social Issues, 66(1), 79-94.

Ramirez, J. David; Yuen, Sandra D.; and Ramey, Dena R. 1991. Final Report: Longitudinal Study of Structured Immersion Strategy, Early-Exit, and Late-Exit Transitional Bilingual Education Programs for Language-Minority Children. San Mateo, Calif.: Aguirre International.

Reese, L., Gallimore, R., \& Guthrie, D. (2005). Reading trajectories of immigrant Latino students in transitional bilingual programs. Bilingual research journal, 29(3), 679697.

Slavin, R. E., \& Cheung, A. (2005). A synthesis of research on language of reading instruction for English language learners. Review of Educational Research, 75(2), 247-284.

Slavin, R. E., Madden, N., Calderón, M., Chamberlain, A., \& Hennessy, M. (2011). Reading and language outcomes of a multiyear randomized evaluation of transitional bilingual education. Educational Evaluation and Policy Analysis, 33(1), 47-58.

Tong, F., Irby, B. J., Lara-Alecio, R., \& Mathes, P. G. (2008a). English and Spanish acquisition by Hispanic second graders in developmental bilingual programs: A 3year longitudinal randomized study. Hispanic Journal of Behavioral Sciences.

Tong, F., Lara-Alecio, R., Irby, B., Mathes, P., \& Kwok, O. M. (2008b). Accelerating early academic oral English development in transitional bilingual and structured English immersion programs. American Educational Research Journal, 45(4), 10111044.

U.S. Census Bureau: The Hispanic Population: 2010 (May 2011) Retrieved from http:// www.census.gov/prod/cen2010/briefs/c2010br-04.pdf on September 2015.

Valentino, R. A., \& Reardon, S. F. (2015). Effectiveness of four instructional programs designed to serve English learners: Variation by ethnicity and initial English proficiency. Educational Evaluation and Policy Analysis. DOI 10.3102/01623737 15573310.

Willig, A. C. (1985). A meta-analysis of selected studies on the effectiveness of bilingual education. Review of Educational Research, 55, 269-317. 
Appendix. Summary of Studies Included in Review

Table 1. Summary of Studies with General Outcomes

\begin{tabular}{|c|c|c|c|c|c|}
\hline Author(s) & Purpose & Sample & Program Description & Measures & $\begin{array}{l}\text { Evidence of Significant Effects of Bilingual } \\
\text { Model/Results/Notes }\end{array}$ \\
\hline $\begin{array}{l}\text { Anderberg, \& } \\
\text { McSparran } \\
\text { Ruby (2013) }\end{array}$ & $\begin{array}{l}\text { Examine whether there were } \\
\text { significant differences in SP and } \\
\text { in ENG receptive vocabulary } \\
\text { development of preschool } \\
\text { students in either, TWI, TBP, or } \\
\text { EngO programs. }\end{array}$ & $\begin{array}{l}\text { 45; Preschool; } \\
\text { ENG/SP }\end{array}$ & $\begin{array}{l}\text { EngO, TBP } \\
\text { (L1 with } 20 \text { min of ENG); } \\
\text { DLP }\end{array}$ & $\begin{array}{l}\text { ENG: PPVT-3 } \\
\underline{\text { SP: TVIP }}\end{array}$ & $\begin{array}{l}\text { PPVT - Gains in English receptive vocabulary } \\
\text { across the } 2 \text {-year period in all three programs; } \\
78 \% \text { of students in TBE made gains in English. } \\
\text { No gains in SP across groups. }\end{array}$ \\
\hline $\begin{array}{l}\text { Valentino \& } \\
\text { Reardon } \\
(2014)\end{array}$ & $\begin{array}{l}\text { Examine the differential effects } \\
\text { of four English Immersion } \\
\text { instructional programs (TBE, } \\
\text { developmental bilingual, TWI, } \\
\text { and ENG immersion) on ELs' } \\
\text { academic growth in ELA and } \\
\text { math through middle school }\end{array}$ & $\begin{array}{l}\text { 13,750 ELs (2,573 } \\
\text { TBE; } 2,771 \text { DB; } \\
\text { 1,113 DI; } 7,793 \\
\text { EI); 2-5; } \\
\text { ENG/SP/Chinese }\end{array}$ & $\begin{array}{l}\text { TBE: } 50-90 \% \text { in ENG. Out by } \\
\text { 3rd grade. } \\
\text { Developmental: } 50-90 \% \text { in } \\
\text { ENG, out by 5th grade. } \\
\text { TWI: } 80-90 \% \text { in target } \\
\text { language in Grades K-1, 50:50 } \\
\text { by Grade } 5 \\
\text { ENG Immersion: } 100 \% \text { of } \\
\text { instruction in ENG + at least } \\
30 \text { min/day ELD support }\end{array}$ & $\begin{array}{l}\underline{\text { State standardized }} \\
\underline{\text { tests of ENG }} \\
\underline{\text { Language Arts \& }} \\
\underline{\text { Mathematics }}\end{array}$ & $\begin{array}{l}\text { Students in EI demonstrated similar rates of } \\
\text { growth to average student in the state and were } \\
\text { not distinguishable of students receiving TBE or } \\
\text { TWI instruction. } \\
\text { Students in TWI, who exhibited lowest scores in } \\
\text { Grade } 2 \text {, increased at a rate as much as } 0.09 \text { SD } \\
\text { faster per grade than students in other programs. } \\
\text { We must consider the initial differences in } \\
\text { students at the start of the program, because this } \\
\text { could demonstrate benefits on closing the gap } \\
\text { between EngO and participants of DLPs. }\end{array}$ \\
\hline
\end{tabular}


Table 2. Summary of Studies Comparing TBE and English-Only Programs and SEI

\begin{tabular}{|c|c|c|c|c|c|}
\hline Author(s) & Purpose & Sample & Program Description & Measures & $\begin{array}{l}\text { Evidence of Significant Effects of Bilingual } \\
\text { Model/Results/Notes }\end{array}$ \\
\hline $\begin{array}{l}\text { Tong, Irby, } \\
\text { Lara-Alecio, \& } \\
\text { Mathes (2008) }\end{array}$ & $\begin{array}{l}\text { Evaluate ENG and SP language } \\
\text { and literacy outcomes } \\
\text { longitudinally (Grades K-2) for } \\
\text { students participating in a TBE } \\
\text { enhanced program vs. typical } \\
\text { TBP }\end{array}$ & $\begin{array}{l}262(141 \\
\text { enhanced TBP: } \\
121 \text { typical TBP); } \\
\text { K-2; ENG/SP }\end{array}$ & $\begin{array}{l}\text { Enhanced TBP }=70 / 30 \\
\text { SP/ENG (70/30 in K, 60/40 in } \\
\text { Grade } 1,50 / 50 ; \text { all SP } \\
\text { instruction in content areas } \\
\text { until spring of Grade } 2) \\
\text { TBP implementing 'typical' } \\
\text { practices }(80 / 20 \text { in } \mathrm{K}, 70 / 30 \text { in } \\
1,60 / 40 \text { in } 2 ; 45 \text { min ESL) }\end{array}$ & $\begin{array}{l}\text { ENG: Letter } \\
\text { naming and letter } \\
\text { sound; CTOPP; } \\
\text { WLBP-R; DIBELS } \\
\text { SP: TOPP-S; } \\
\text { WLPB-R; } \\
\text { DIBELS-S }\end{array}$ & $\begin{array}{l}\text { ELs in enhanced TBE outperformed ELs in TBP } \\
\text { on ENG measures (ES ranged from } 0.12 \text { to } \\
0.72 \text { ), and on SP measures (ES ranged from } 0.19 \\
\text { to } 0.38 \text { ). ENG proficiency was below the norm }\end{array}$ \\
\hline $\begin{array}{l}\text { Proctor, } \\
\text { August, Carlo, } \\
\& \text { Barr (2010) }\end{array}$ & $\begin{array}{l}\text { Investigate the reading } \\
\text { comprehension growth of SP- } \\
\text { ENG B receiving reading } \\
\text { instruction in one of three } \\
\text { models - EngO, SP-only, and } \\
\text { TBE }\end{array}$ & $\begin{array}{l}101(34 \mathrm{~B} ; 22 \mathrm{SP}- \\
\text { only; } 45 \mathrm{EngO}) ; 2- \\
5 ; \mathrm{ENG} / \mathrm{SP}\end{array}$ & $\begin{array}{l}\text { Bilingual - transitioned out of } \\
\text { SP instruction into ENG after } \\
\text { 2nd, 3rd, or 4th grade once } \\
\text { attained 2nd grade proficiency } \\
\text { in SP literacy }\end{array}$ & $\begin{array}{l}\text { ENG: WLPB-R } \\
\text { SP: WLPB-R }\end{array}$ & $\begin{array}{l}\text { Students in the ENG-only and bilingual groups } \\
\text { significantly outperformed SP-instructed peers } \\
\text { on ENG reading comprehension } \\
\text { For SP-only, and bilingual groups only SP and } \\
\text { ENG reading comprehension were significantly } \\
\text { correlated }(\mathrm{r}=.61 \text { and } .77, \mathrm{p}<.01)\end{array}$ \\
\hline $\begin{array}{l}\text { Reese, } \\
\text { Gallimore, \& } \\
\text { Guthrie (2005) }\end{array}$ & $\begin{array}{l}\text { Examine how well SP-speaking } \\
\text { students in transitional bilingual } \\
\text { programs perform in ENG and } \\
\text { SP reading in elementary and } \\
\text { middle school }\end{array}$ & $\begin{array}{l}91 \text { (22 with some } \\
\text { ENG proficiency); } \\
\text { K-5; ENG/SP }\end{array}$ & $\begin{array}{l}\text { TBE - moves to EngO when } \\
\text { reading ability in SP is at the } \\
\text { third grade level, and have } \\
\text { conversational ability in ENG }\end{array}$ & $\begin{array}{l}\text { ENG: CTBS; } \\
\text { MAT; IDEA } \\
\text { Proficiency Task; } \\
\text { BSM; ITBS; } \\
\text { TAAS; ITAS } \\
\text { SP: SABE; CTBS- } \\
\text { S; Prueba de } \\
\text { Lectura Inicial } \\
\end{array}$ & $\begin{array}{l}\text { Scores for all students decreased when they } \\
\text { transitioned from SP to ENG. Those with better } \\
\text { scores transitioned earlier (Grades } 2 \text { or } 3 \text { ) and } \\
\text { improved earlier. By Grade } 7 \text {, grade of transition } \\
\text { was negatively correlated with performance ( } \mathrm{r}= \\
-.48, \mathrm{p}<.01)\end{array}$ \\
\hline $\begin{array}{l}\text { Slavin, } \\
\text { Madden, } \\
\text { Calderon, } \\
\text { Chamberlain, \& } \\
\text { Hennessy } \\
(2011)\end{array}$ & $\begin{array}{l}\text { Compare the effectiveness of } \\
\text { TBE and SEI in supporting the } \\
\text { literacy development of SP- } \\
\text { speaking ELs over time }\end{array}$ & $\begin{array}{l}801(421 \mathrm{TBE} \\
380 \mathrm{SEI}) ; \mathrm{K}-4 \\
\text { ENG/SP }\end{array}$ & $\begin{array}{l}\text { TBE - All instruction provided } \\
\text { in SP in K; then SP and ENG } \\
\text { until EngO in grade } 3 \text {; SEI - } \\
\text { All reading instruction using } \\
\text { SFA materials, + ESL sessions }\end{array}$ & $\begin{array}{l}\text { ENG: PPVT; } \\
\text { WLPB-R } \\
\text { SP: TVIP; WLPB- } \\
\text { R }\end{array}$ & $\begin{array}{l}\text { Grade 3-4 - No significant difference in ENG } \\
\text { between ELs receiving SEI or TBE } \\
\text { No significant difference in SP reading } \\
\text { outcomes, except for passage comprehension in } \\
\text { grade } 4(\mathrm{~d}=.39)\end{array}$ \\
\hline
\end{tabular}


Table 3. Summary of Studies Comparing TWI and English-Only Programs

\begin{tabular}{|c|c|c|c|c|c|}
\hline Author(s) & Purpose & Sample & Program Description & Measures & $\begin{array}{l}\text { Evidence of Significant Effects of Bilingual } \\
\text { Model/Results/Notes }\end{array}$ \\
\hline $\begin{array}{l}\text { Barnett, } \\
\text { Yarosz, } \\
\text { Thomas, } \\
\text { Jung, \& } \\
\text { Blanco } \\
(2007)\end{array}$ & $\begin{array}{l}\text { Compare the effects of a TWI } \\
\text { and EngO program on language } \\
\text { and literacy skills of } 3 \text { - and } 4- \\
\text { year olds }\end{array}$ & $\begin{array}{l}131 \text { ( } 85 \text { TWI; } 52 \\
\text { EngO); preschool; } \\
\text { ENG/SP }\end{array}$ & $\begin{array}{l}\text { TWI }(8 \mathrm{hr} / \text { day for } 200+ \\
\text { school days) alternating ENG } \\
\text { and SP weekly by rotating } \\
\text { students between } \\
\text { classrooms/teachers } \\
\text { EngO: } 6 \mathrm{hr} / \text { day for } 180+ \\
\text { school days }\end{array}$ & $\begin{array}{l}\text { ENG: PPVT-3, WJ- } \\
\text { R; } \\
\text { SP: TVIP, WM-R; } \\
\text { Other Measures: } \\
\text { ECERS-R; SELA; } \\
\text { SELLCA }\end{array}$ & $\begin{array}{l}\text { No significant effects on all ENG outcomes; } \\
\text { Significant effects in SP favoring TWI for EOs } \\
\text { and ELs (Receptive Vocabulary, ES = 0.61). No } \\
\text { differences in classroom quality. }\end{array}$ \\
\hline $\begin{array}{l}\text { Lindholm- } \\
\text { Leary \& } \\
\text { Block (2010) }\end{array}$ & $\begin{array}{l}\text { Examine how two groups of } \\
\text { Hispanic students: English } \\
\text { proficient (EP) and ELs in Dual } \\
\text { Language Program (aka. TWI) } \\
\text { perform on ELA compared to } \\
\text { English-only in low SES schools. }\end{array}$ & $\begin{array}{l}659 \text { (Study 1: } 193 \\
\text { total; } 81 \text { EP - } 28 \\
\text { in TWI, } 23 \text { in } \\
\text { EngO; } 112 \text { ELs - } \\
62 \text { in TWI and } 50 \\
\text { in EngO); Study 2: } \\
446 \text { total, } 207 \text { in } \\
\text { DLP and } 259 \text { in } \\
\text { EngO), } 4-6 ; \\
\text { ENG/SP }\end{array}$ & $\begin{array}{l}\text { TWI - } 90 \% \text { in SP in K\& } 1 \text {, } \\
80 \% \text { in grade } 2,70 \% \text { in grade } \\
3,60 \% \text { in grade } 4, \text { and } 50 \% \\
\text { from grade } 5 \text { on. Control } \\
\text { group: English-only }\end{array}$ & $\begin{array}{l}\text { ENG: ELA and } \\
\text { California } \\
\text { Standards Test, SP: } \\
\text { Aprenda }\end{array}$ & $\begin{array}{l}\text { ENG: In Study 1, significant differences between } \\
\text { EP and EL students in a TWI and their peers in } \\
\text { EngO in ELA assessments. In study 2, both EP } \\
\text { and EL students in a TWI achieved at } \\
\text { significantly higher levels than their peers in } \\
\text { EngO on the ELA assessment (d =0.71 for EP } \\
\text { group, } d=\eta 20.35 \text { for EL group). Both EP and } \\
\text { EL students in TWI scored above grade level on } \\
\text { Aprenda reading subtest. }\end{array}$ \\
\hline $\begin{array}{l}\text { Lopez \& } \\
\text { Tashakkori } \\
\text { (2004a) }\end{array}$ & $\begin{array}{l}\text { Investigate the effects of a Two } \\
\text { Way Immersion program on the } \\
\text { English language development of } \\
\text { ESOL (Level } 3 \text { and } 4 \text { ) and } \\
\text { proficient ENG speakers }\end{array}$ & $\begin{array}{l}215 \text { (117 ESOL; } \\
98 \text { ENG } \\
\text { proficient); 5; } \\
\text { ENG/SP }\end{array}$ & $\begin{array}{l}\text { TWI - ENG } 70 \%, \text { SP } 30 \% \text { vs. } \\
\text { ENG } 90 \% \text {. } \\
\text { ESOL: ENG } 90 \%, \text { SP } 10 \%\end{array}$ & $\begin{array}{l}\text { ENG: Kindergarten } \\
\text { Assessment Guide; } \\
\text { SRI }\end{array}$ & $\begin{array}{l}\text { No differences between groups in English. After } \\
1 \text { year no significant gaps between groups. } \\
\text { Baseline scores on the experimental group were } \\
\text { lower. }\end{array}$ \\
\hline $\begin{array}{l}\text { Lopez \& } \\
\text { Tashakkori } \\
(2004 b)\end{array}$ & $\begin{array}{l}\text { Compare the academic } \\
\text { performance and attitudes of fifth } \\
\text { grade students with different L2 } \\
\text { proficiency levels who had been } \\
\text { enrolled in TBE vs. EngO }\end{array}$ & $\begin{array}{l}66 \text { (33 two-way } \\
\text { Bilingual; } 33 \\
\text { ENG); K-1; } \\
\text { ENG/SP }\end{array}$ & $\begin{array}{l}\text { EFL program } 70 / 30 \\
\text { ENG instruction- All } \\
\text { instruction in ENG except } 2.5 \\
\text { hrs/week of SP language arts }\end{array}$ & ENG: SRI & $\begin{array}{l}\text { No differences between the groups suggesting } \\
\text { that students at risk were able to catch up to their } \\
\text { peers at the end of grade } 1 .\end{array}$ \\
\hline
\end{tabular}


Table 4. Summary of Studies Comparing TWI and TBE

\begin{tabular}{|c|c|c|c|c|c|}
\hline Author(s) & Purpose & Sample & Program Description & Measures & $\begin{array}{l}\text { Evidence of Significant Effects of Bilingual } \\
\text { Model/Results/Notes }\end{array}$ \\
\hline $\begin{array}{l}\text { Lopez \& } \\
\text { Tashakkori } \\
\text { (2006) }\end{array}$ & $\begin{array}{l}\text { Investigate the impact of an } \\
\text { extended English as a foreign } \\
\text { language program compared to } \\
\text { EngO on the language } \\
\text { development of ELs at-risk in K } \\
\text { by comparing them with a group } \\
\text { of students with greater ENG } \\
\text { proficiency }\end{array}$ & $\begin{array}{l}344 \text { (205 TWI; } \\
139 \text { TBE) }\end{array}$ & $\begin{array}{l}\text { TWI }-(60 \% \text { of instruction in } \\
\text { ENG, } 40 \% \text { in SP }) \text { TBE - } \\
\text { EngO with the onption of } \\
\text { receiving } 2.5 \text { hrs of SP during } \\
\text { the week. }\end{array}$ & $\begin{array}{l}\text { ENG: FCAT } \\
\text { SP: EDL } \\
\text { Interview \& } \\
\text { questionnaire to } \\
\text { measure attitudes } \\
\text { and self-report of } \\
\text { ENG and SP } \\
\text { proficiency }\end{array}$ & $\begin{array}{l}\text { ELs in TWI required less time on average to } \\
\text { learn ENG compared to ELs in TBE. ELs in TWI } \\
\text { with lower ENG proficiency, exited the ENG as } \\
\text { a second language courses faster than ELs in the } \\
\text { TBE ( } 2=.04) \text {. ELs in TWBE scored better in } \\
\text { SP outcomes ( } \eta 2=0.26) \\
\text { Attitudes toward bilingualism - Students in TWI } \\
\text { had more positive attitudes toward bilingualism } \\
\text { than students in the TBE program for ENG and } \\
\text { for SP ( } \eta 2=.07) \text {; No significant differences in } \\
\text { reading, math and science outcomes between } \\
\text { groups. }\end{array}$ \\
\hline $\begin{array}{l}\text { Marian, } \\
\text { Shook, \& } \\
\text { Schroeder } \\
(2013)\end{array}$ & $\begin{array}{l}\text { Examine whether TWI programs } \\
\text { benefit academic achievement } \\
\text { for both minority- and majority } \\
\text { language students by comparing } \\
\text { performance of minority- } \\
\text { language students enrolled in } \\
\text { TWI to performance of minority- } \\
\text { language students in a TBE }\end{array}$ & $\begin{array}{l}2009 \text { (157 TWI; } \\
23 \text { Transitional } \\
\text { Program of } \\
\text { ENG/ESL; } 75 \\
\text { ENG dominant in } \\
\text { TWI; } 1777 \text { ENG } \\
\text { only); 3-5; } \\
\text { ENG/SP }\end{array}$ & $\begin{array}{l}\text { TWI-S:SP in Grades K-2, } \\
\text { ENG in Grades 3-5 (math - SP } \\
\text { K-3, ENG; 4-5; social } \\
\text { studies/science - SP) } \\
\text { TBP - ENG with pull out ESL } \\
\text { instruction as needed } \\
\text { TWI-E: ENG in Grades K-2; } \\
\text { SP instruction in Grades 3-5 } \\
\text { (math - SP K-3, ENG 4-5; } \\
\text { social studies/science - SP K- } \\
\text { 5) }\end{array}$ & $\begin{array}{l}\text { State Measure of } \\
\text { Annual Growth in } \\
\text { ENG; State } \\
\text { Standards } \\
\text { Achievement Test }\end{array}$ & $\begin{array}{l}\text { Significant improvement in reading growth } \\
\text { across grade levels, with higher scores in later } \\
\text { grades in ENG (relative to students in lower } \\
\text { grades) - X } 2=31.0, \mathrm{p}<.001, \eta 2=.24 \text { ) whereas } \\
\text { similar improvement not observed in TBE group } \\
\text { For Grade } 3 \text {, TWI-E students outperformed MC } \\
\text { students in Reading, }(\mathrm{p}<.001) \text {, difference in } \\
\text { mean ranks }=141, \mathrm{r}=.19)\end{array}$ \\
\hline
\end{tabular}


Table 5. Summary of Studies Demonstrating Effective Instruction

\begin{tabular}{|c|c|c|c|c|c|}
\hline Author(s) & Purpose & Sample & Program Description & Measures & $\begin{array}{l}\text { Evidence of Significant Effects of Bilingual } \\
\text { Model/Results/Notes }\end{array}$ \\
\hline $\begin{array}{l}\text { Anderberg, \& } \\
\text { McSparran } \\
\text { Ruby (2013) }\end{array}$ & $\begin{array}{l}\text { Examine whether there were } \\
\text { significant differences in SP and } \\
\text { in ENG receptive vocabulary } \\
\text { development of preschool } \\
\text { students in either, TWI, TBE, or } \\
\text { EngO programs. }\end{array}$ & $\begin{array}{l}\text { 45; Preschool; } \\
\text { ENG/SP }\end{array}$ & $\begin{array}{l}\text { EngO, TBE } \\
\text { (L1 with } 20 \text { min of ENG); } \\
\text { DLP }\end{array}$ & $\begin{array}{l}\text { ENG: PPVT-3 } \\
\text { SP: TVIP }\end{array}$ & $\begin{array}{l}\text { PPVT - Gains in English receptive vocabulary } \\
\text { across the } 2 \text {-year period in all three programs; } \\
78 \% \text { of students in TBE made gains in English. } \\
\text { No gains in SP across groups. }\end{array}$ \\
\hline $\begin{array}{l}\text { Barnett, } \\
\text { Yarosz, } \\
\text { Thomas, } \\
\text { Jung, \& } \\
\text { Blanco } \\
(2007)\end{array}$ & $\begin{array}{l}\text { Compare the effects of a TWI } \\
\text { and EngO program on language } \\
\text { and literacy skills of 3- and 4- } \\
\text { year olds }\end{array}$ & $\begin{array}{l}131 \text { ( } 85 \text { TWI; } 52 \\
\text { EngO); preschool; } \\
\text { ENG/SP }\end{array}$ & $\begin{array}{l}\text { TWI }(8 \mathrm{hr} / \text { day for } 200+ \\
\text { school days) alternating ENG } \\
\text { and SP weekly by rotating } \\
\text { students between } \\
\text { classrooms/teachers } \\
\text { EngO: } 6 \mathrm{hr} / \text { day for } 180+ \\
\text { school days }\end{array}$ & $\begin{array}{l}\text { ENG: PPVT-3, WJ- } \\
\text { R; } \\
\text { SP: TVIP, WM-R; } \\
\text { Other Measures: } \\
\text { ECERS-R; SELA; } \\
\text { SELLCA }\end{array}$ & $\begin{array}{l}\text { No significant effects on all ENG outcomes; } \\
\text { Significant effects in SP favoring TWI for EOs } \\
\text { and ELs (Receptive Vocabulary, ES = 0.61). No } \\
\text { differences in classroom quality. }\end{array}$ \\
\hline $\begin{array}{l}\text { Calhoon, Al } \\
\text { Otaiba, } \\
\text { Cihak, King, } \\
\text { \& Avalos } \\
(2008)\end{array}$ & $\begin{array}{l}\text { Examine effects of a } \\
\text { supplemental peer-mediated } \\
\text { reading program on reading } \\
\text { achievement of ELs and EOs in } \\
\text { TWI }\end{array}$ & $\begin{array}{l}76 ; 24 \text { were ELs } \\
\text { (43 PALS; } 33 \text { core } \\
\text { instruction); } 1 ; \\
\text { ENG/SP }\end{array}$ & $\begin{array}{l}\text { TWI with } 60 \text { PALS sessions of } \\
30-35 \text { min. } 3 \text { x per week for } 20 \\
\text { weeks vs. TWI without PALS }\end{array}$ & $\begin{array}{l}\text { ENG: DIBELS } \\
\text { LNF, PSF, NWF, } \\
\text { ORF }\end{array}$ & $\begin{array}{l}\text { Significant time } \mathrm{x} \text { condition interaction favoring } \\
\text { PALS for PSF, NWF, and ORF }(\mathrm{ES}=.53, .50 \text {, } \\
.51) \text {. ELs receiving PALS instruction } \\
\text { outperformed control group }(\mathrm{ES}=1.29,1.15, \\
\text { and } .38 \text { for NWF, LNF, and ORF) }\end{array}$ \\
\hline $\begin{array}{l}\text { Cena, Baker, } \\
\text { Kame'enui, } \\
\text { Baker, Park, } \\
\text { Smolkowski } \\
(2013)\end{array}$ & $\begin{array}{l}\text { Examine effects of daily 15-min } \\
\text { explicit and systematic SP } \\
\text { vocabulary instruction in a TBE } \\
\text { on ELs vocabulary knowledge } \\
\text { and ORF in SP, and bilingual } \\
\text { verbal ability }\end{array}$ & $\begin{array}{l}50 \text { SP-speaking } \\
\text { ELs ( } 24 \text { in } \\
\text { treatment, } 26 \text { in } \\
\text { control); } 1 \text {; } \\
\text { ENG/SP }\end{array}$ & $\begin{array}{l}\text { TBE (Reading in SP with } 30 \\
\text { min. ELD) } \\
\text { Vocabulary Intervention: } \\
\text { Taught } 32 \text { vocabulary words } \\
\text { over } 8 \text { weeks using scripted } \\
\text { lessons. }\end{array}$ & $\begin{array}{l}\text { SP: DOK SP } \\
\text { Vocabulary; TVIP; } \\
\text { IDEL FLO; BVAT }\end{array}$ & $\begin{array}{l}\text { Treatment group significantly outperformed } \\
\text { control group on DOK definitions }(\eta 2=0.20) \text {, } \\
\text { DOK usage }(\eta 2=0.10) \text {, and DOK total scores } \\
\text { ( } \eta 2=0.17) \text {. No effects on bilingual verbal } \\
\text { ability. }\end{array}$ \\
\hline
\end{tabular}

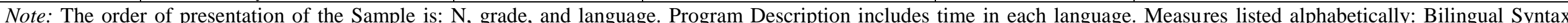

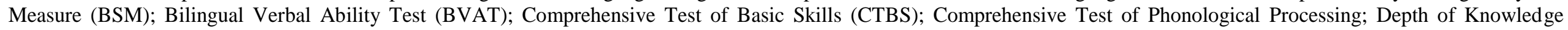

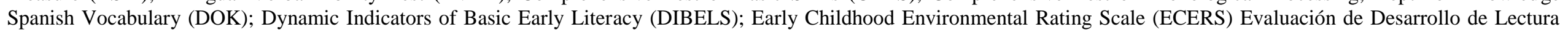

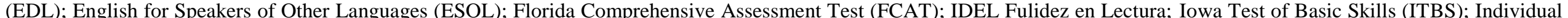

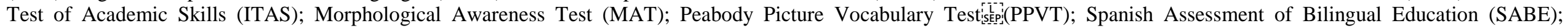

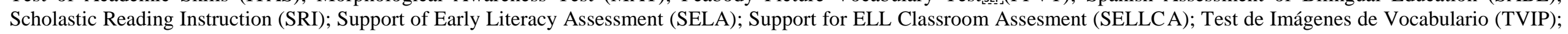

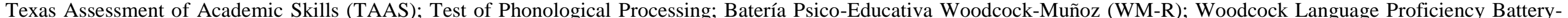

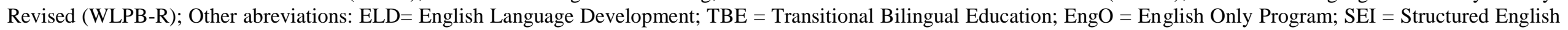
Immersion; EO = English Only; EL = English Learners; EP = English Proficient; ENG = English Language; SP = Spanish Language. 